\title{
Kształcenie nauczycieli edukacji elementarnej w Polsce i wybranych krajach europejskich
}

\section{Wzrost znaczenia edukacji przedszkolnej}

W ostatnich dziesięcioleciach przywiązuje się coraz większą wagę do edukacji przedszkolnej, podkreślając, że jest istotnym elementem ogniwa systemu edukacji. Wiek przedszkolny to początek kształtowania się osobowości człowie$\mathrm{ka}$, a także ogromne rezerwy niewykorzystanych w pełni możliwości rozwoju dzieci, zwłaszcza tych, którym uniemożliwia się korzystanie z przedszkola.

Zainteresowanie wychowaniem przedszkolnym wynika nie tylko z powodu upowszechnienia wychowania przedszkolnego, o którym już wspominano na początku lat 70. XX wieku, ale także podkreśla się znaczenie edukacji przedszkolnej funkcjonującej na wysokim poziomie, jej szczególną rolę we wspomaganiu rodziny $\mathrm{w}$ zapewnieniu korzystnych warunków rozwoju dziecka oraz wyrównywaniu szans edukacyjnych.

Edukacja jest czynnikiem zapewniającym pomyślny rozwój państwa. Kreowanie gospodarki opartej na wiedzy to przede wszystkim konieczność nieustannego inwestowania $\mathrm{w}$ naukę, edukację oraz $\mathrm{w}$ intensywne kształcenie, szkolenie i doskonalenie zawodowe nauczycieli.

\section{Kompetencje zawodowe nauczyciela wczesnej edukacji}

Wzrasta świadomość potrzeby zmian w rozumieniu roli nauczyciela w perspektywie edukacyjnej XXI wieku. Standardy nowoczesnej edukacji wymagają nowego spojrzenia na kompetencje nauczycieli. Dziś stwierdza się jednoznacznie, że osoba nauczyciela przesądza o jakości szkoły (przedszkola) i jest w najwyższym stopniu sprawczym czynnikiem rozwoju ucznia (dziecka).

Nauczyciele edukacji przedszkolnej i wczesnoszkolnej odgrywają szczególną rolę. Pomagają w lepszym wykorzystaniu możliwości dzieci, w osiąganiu dobrego samopoczucia, w zdobywaniu szerokiego zakresu wiedzy i umiejętności, potrzebnego $\mathrm{w}$ dalszej edukacji, także $\mathrm{w}$ dorosłym życiu. To właśnie 
nauczyciele są pośrednikami pomiędzy szybko zmieniającym się światem a uczniami, którzy dopiero w niego wkraczają. Zawód nauczyciela staje się coraz bardziej złożony, a środowisko, w którym pracują pedagodzy jest coraz bardziej wymagające ${ }^{1}$.

Unia Europejska lansuje model nauczyciela, który powinien:

1) posiadać wykształcenie akademickie,

2) być kreatywnym i otwartym na wiedzę (umieć uczyć się „,innowacyjnie”) oraz zdolnym kształtować te umiejętności u swoich wychowanków,

3) sprawować nie tylko funkcję „kształceniową”, lecz również opiekuńczą, orientująca, selekcyjną i koordynująca,

4) mieć zamiłowanie do swojej pracy,

5) szybko i racjonalnie reagować na to, co postępowe i twórcze,

6) ustawicznie doskonalić umiejętności zawodowe.

Kompetencje zawodowe nauczycieli UE/ATEE (Association of Teacher Education In Europe) to:

1) posługiwanie się różnorodnymi źródłami wiedzy i nowoczesnymi technologiami informacyjnymi,

2) współpraca z podmiotami tworzącymi przestrzeń edukacyjną (uczniowie, nauczyciele, rodzice, samorząd lokalny itp. ),

3) współpraca ze społeczeństwem i w społeczeństwie ${ }^{2}$.

Dokumenty „unijne” podkreślają, że jest to zawód o wysokich kwalifikacjach. Wszyscy nauczyciele posiadają dyplom instytucji szkolnictwa wyższego. Każdy nauczyciel ma szeroką wiedzę dotyczącą swego przedmiotu, dobrą znajomość zagadnień pedagogicznych oraz kompetencje wymagane do prowadzenia i wspierania uczących się, jak i zrozumienie społecznego, i kulturowego wymiaru kształcenia. Ponadto specyfiką osób pracujących w tym zawodzie jest uczenie się przez całe życie. Nauczyciel będzie stawać się przewodnikiem i thumaczem ${ }^{3}$.

Już pod koniec XX wieku w raporcie J. Delors'a czytaliśmy, że będą wzrastać oczekiwania wobec nauczycieli, którzy powinni rozbudzać ciekawość, rozwijać samodzielność, zachęcać do „intelektualnej ścisłości” oraz tworzyć warunki niezbędne do edukacji formalnej i edukacji ustawicznej. Nauczyciel traktowany jest przez Komisję jako przyszły promotor zmian, orędownik wzajemnego zrozumienia i tolerancji ${ }^{4}$.

\footnotetext{
${ }^{1}$ Komunikat Komisji do Rady i Parlamentu Europejskiego „Poprawa jakości ksztatcenia nauczycieli" z dn. 23 sierpnia $2007 \mathrm{r}$.

${ }^{2}$ M. Żytko, Kształcenie nauczycieli edukacji elementarnej $w$ Polsce, [w:] http://www. dladzieci.org.pl, dostęp 2010-04-02.

${ }^{3}$ Por. Nauczanie i uczenie się. Na drodze do uczqcego się społeczeństwa. Biała Księga Ksztatcenia i Doskonalenia, Warszawa 1997, s. 51.

${ }^{4}$ Edukacja - jest w niej ukryty skarb. Raport dla UNESCO pod przew. J. Delors'a, Warszawa 1998 , s. 147 i n.
} 
Szkoła i nauczyciele stają się, zdaniem ekspertów Międzynarodowej Komisji ds. Edukacji i Oświaty dla XXI wieku pod przewodnictwem J. Delors'a, ważnym elementem sprawczym rozwoju współczesnych społeczeństw. A dzieje się to poprzez cztery filary działalności tej instytucji, które stają się równocześnie filarami wiedzy każdego ucznia:

- uczyć się, aby wiedzieć,

- uczyć się, aby działać,

- uczyć się, aby żyć wspólnie,

- uczyć się, aby byćs.

Oczekuje się od nauczycieli sprostania coraz bardziej złożonym problemom społecznym (ubóstwo, głód, przemoc, narkotyki...). Im większe przeszkody ma do pokonania uczeń - tym więcej wymaga się od nauczyciela. Aby jego działania były skuteczne, powinien dysponować różnorodnymi kompetencjami pedagogicznymi, zaś cenne okazują się następujące zalety: autorytet, empatia, cierpliwość i skromność. Podstawą autorytetu nauczyciela nie będzie już bezgraniczna władza nad uczniem, ale uznanie prawomocności wiedzy ${ }^{6}$.

\section{Zmiana roli nauczyciela pracującego z małym dzieckiem}

Nauczycielskie umiejętności pedagogiczne służą efektywnemu konstruowaniu, organizowaniu i zarządzaniu procesem kształcenia oraz korzystaniu z wolności dokonywania wyboru, a także i podejmowania decyzji.

A. Kotusiewicz już pod koniec lat 90. XX wieku dostrzegała ewolucję funkcji zawodowych nauczyciela i sygnalizowała następujące tendencje:

- od funkcji adaptacyjnych kształcenia do funkcji kreatywnych,

- od orientacji procesu dydaktycznego na uczniu (a zwłaszcza jego sferze intelektualnej) do wzajemnej humanizacji procesu kształcenia,

- od przerostu funkcji dydaktycznych do wzrostu roli funkcji wychowawczych,

- od zdominowania szkoły funkcją przekazu systemu wiedzy do uwzględnienia przekazu systemu wartości,

- od przymusu i rygoru do zwiększania zakresu działań samorządowych i autonomicznych ${ }^{7}$.

Również H. Kwiatkowska, uwzględniając perspektywę edukacji młodego człowieka do życia w społeczeństwie wiedzy, dynamicznego przyspieszenia i rosnącego ryzyka, wskazuje nowe kierunki ewolucji profesji nauczycielskiej:

- od przekazu wiedzy do uczenia samodzielności poznawczej i egzystencjalnej,

- od sterowania do inspirowania rozwoju,

\footnotetext{
${ }^{5}$ Tamże, s.85 i n..

${ }^{6}$ Tamże, s. 149 i 153.

${ }^{7}$ A. Kotusiewicz, Kształcenie nauczycieli a problemy wspótczesnej edukacji, Warszawa 1989, s.141.
} 
- od prostego przekazu do wprowadzania ucznia w świat wiedzy,

- od funkcji przekazu wiedzy do czynienia ładu w informacjach,

- od dominacji intelektu do równowagi świata myśli i uczuć w edukacji szkolnej,

- od alternatywy do dialogu ${ }^{8}$.

Ulega zmianie rola nauczyciela wczesnej edukacji (dzieci 3-10 lat). Zamiast roli instruktora: obserwator diagnozujący rozwój dziecka, organizator indywidualnego rozwoju, oraz mediator i partner dbający o optymalny rozwój ${ }^{9}$.

B. Spodek i O. N. Saracho (1990) piszą o 4 obszarach wiedzy, umiejętności i wartości nauczyciela małych dzieci ${ }^{10}$. Dotyczą one:

1) wiedzy psychologicznej i pedagogicznej,

2) wiedzy o konstruowaniu programu wspierającego indywidualny rozwój,

3) wiedzy o metodach tworzenia bezpiecznego i stymulującego uczenie się środowiska edukacyjnego,

4) wiedzy o monitorowaniu rozwoju dziecka i ewaluacji efektów pracy nauczyciela.

Rozwinięcie poczucia świadomości i odpowiedzialności za proces edukacji.

Powinniśmy dysponować nauczycielami, którzy śledzq postępy każdego dziecka i staraja się zwaloryzować potencjat każdego ucznia, ponieważ każdy $z$ nich jest niepowtarzalnq osobowościq ${ }^{11}$. Nauczyciele powinni kontynuować proces edukacyjny poza instytucją szkolną, organizując odpowiednie formy nauczania. Ważne $w$ ich działaniu staje się nawiązanie nowego rodzaju relacji z uczniem:

- od roli „solisty” do roli ,akompaniatora”,

- być odtąd nie tyle szafarzem wiadomości, ile przewodnikiem ucznia w jego poszukiwaniu, organizowaniu i posługiwaniu się wiedza,

- kierować umysłami raczej niż je modelować, okazując wszelako wielką stanowczość w odniesieniu do fundamentalnych wartości będących drogowskazami życia ${ }^{12}$.

Nauczyciel łaczy $w$ swej działalności sprzeczne zadania: jest specjalista przedmiotowym i przekazuje do zapamiętania gotowq wiedze, a jednocześnie jest (powinien być) przewodnikiem dzieci i młodzieży, pomagajacym odnajdywać im sens ich życia, budować indywidualna tożsamość: powinien także umieć być doradca $i$ terapeuta konkretnych dzieci ${ }^{13}$. W rolę nauczyciela wpisane jest

${ }^{8}$ H. Kwiatkowska, Pedeutologia, Warszawa 2008, s. 40.

${ }^{9}$ M. Żytko, Ksztatcenie nauczycieli...

${ }^{10}$ A. Blumsztajn, T. Szlendak, Raport o sytuacji edukacji elementarnej, http://www.frd.org. pl/repository/upload/raport_o_sytuacji_edukacji_elementarnej.pdf, dostęp: 2010-04-02

${ }^{11}$ F. Mayor, Przyszłość świata, Fundacja Studiów i Badań Edukacyjnych, Warszawa 2001, s. 390 .

${ }^{12}$ Edukacja-jest w niej ukryty skarb..., s. 150.

${ }^{13}$ R. Kwiecińska, Z. Kwieciński, Ukryty program ksztatcenia nauczycieli w okresie szybkich przemian, [w:] W. Prokopiuk (red.), Rozwój nauczyciela w okresie transformacji, Białystok 1998, s. 21. 
codzienne wysokie zaangażowanie emocjonalne i intelektualne. Kompetencje, profesjonalizm i oddanie, których wymaga się od nauczycieli, nakładają na nich ogromną odpowiedzialność.

Współczesnym nauczycielom stawia się nowe wymagania:

- oprócz przekazywania podstawowej wiedzy, częściej oczekuje się, że będą pomagali młodym ludziom w osiaganiu samodzielności w uczeniu się (poprzez nabywanie podstawowych kompetencji, niż poprzez uczenie się na pamięć),

- nauczania nastawionego na współpracę, podejścia polegającego na ułatwianiu uczenia się i zarządzaniu klasą,

- zapoznania się z różnymi stylami i metodami nauczania. Grupy (klasy) składają się z dzieci pochodzących z różnych środowisk, posiadających różne zdolności i różny stopień sprawności lub niesprawności,

- wykorzystywania możliwości oferowanych przez nowe technologie i odpowiedzi na potrzebę zindywidualizowanego nauczania,

- nabywania nowej wiedzy i umiejętności, oraz stałego ich rozwijania. Należy więc zapewnić im wysokiej jakości podstawowe wykształcenie pedagogiczne oraz spójny proces ustawicznego doskonalenia zawodowego tak, aby orientowali się w kompetencjach, których wymaga społeczeństwo oparte na wiedzy,

- odpowiedzialności za ciagłe pogłębianie swojej wiedzy zawodowej poprzez refleksję, badania naukowe i systematyczne angażowanie się w ustawiczny rozwój zawodowy przez cały okres swojej kariery zawodowej ${ }^{14}$.

R. Pachociński podkreśla zmieniającą się rolę i funkcje nauczyciela. Wśród priorytetowych zadań wymienia nauczyciela jako: animatora i inspiratora samodzielnej pracy uczniów, diagnostyka, specjalisty i konsultanta, trenera i (lub) eksperta, „model do naśladowania”, czy też propagatora i pierwszego "użytkownika" nowych strategii działania. Nauczyciela, który aby ułatwić proces uczenia się tworzy empatyczne środowisko wychowawcze, gdzie jest miejsce dla wolności i dyscypliny ${ }^{15}$.

Nauczyciel przestaje być gotowym źródłem informacji, lecz staje się przewodnikiem po świecie wiedzy, człowiekiem, który uchyla przed uczniem wielkie wrota do świata wartości, świata idei, postaci, myśli, słów i czynów, świata odkryć naukowych. Mówi: Zapraszam!- Wejdź! Zobacz, ile tu bogactwa! Poznaj je! Doświadcz! Przeżyj! I poszukaj czegoś dla siebie ${ }^{16}$.

Nauczyciele będą musieli, w ciągu całej swej egzystencji, aktualizować i doskonalić swoje wiadomości i swoje techniki, przestrzegając równowagi między kompetencjami w nauczanej dyscyplinie i kompetencjami pedagogicznymi. Obie wspomniane kompetencje są niezbędne, stanowią podstawę rozwija-

${ }^{14}$ Komunikat Komisji do Rady i Parlamentu Europejskiego...

${ }^{15} \mathrm{R}$. Pachociński, Oświata w społeczeństwie informatycznym, „Społeczeństwo Otwarte” 1996, nr 2.

${ }^{16}$ G. Miłkowska-Olejniczak, Edukacja nauczycieli a reforma oświaty, „Kultura i Edukacja” 1998, nr 4, s. 96. 
nia w nauczycielach ich zalet natury etycznej, intelektualnej i emocjonalnej, których oczekuje od nich społeczeństwo ${ }^{17}$.

Nauczyciel powinien cieszyć się uznaniem społeczeństwa oraz mieć autorytet $\mathrm{i}$ odpowiednie warunki pracy ${ }^{18}$. Także $\mathrm{w}$ raporcie F. Mayora dostrzega się troskę o nauczycieli, którzy byli, są i pozostaną filarami edukacji na wszystkich poziomach nauczania ${ }^{19}$.

\section{Kierunki zmian w kształceniu i doskonaleniu nauczycieli edukacji elementarnej}

Biorąc pod uwagę nową wizję szkoły, musimy zwrócić baczną uwagę na kompetencje (w obszarze wiedzy, umiejętności i odpowiedzialności ${ }^{20}$, w jakie powinien być wyposażony nauczyciel. Zadania, jakie ma do wykonania, możliwe są do spełnienia przez nauczyciela o twórczej osobowości, nauczyciela, który jest kreatorem tzn. człowiekiem mającym odwagę zacząć działać inaczej, lubiącym pracować, gdyż praca daje mu satysfakcję.

Kształcenie nauczycieli nie może mieć charakteru instrukcyjno - dyrektywnego (,nauczyciel powinien”). Kierunki zmian w kształceniu i doskonaleniu nauczycieli dotyczą:

- stworzenie spójnego systemu kształcenia i doskonalenia nauczycieli,

- podnoszenie jakości kształcenia i doskonalenia nauczycieli: programy studiów i przygotowanie ,nauczycieli - nauczycieli” (doradcy metodyczni),

- budowanie pomostu między teorią i praktyką edukacyjna,

- zwiększenie znaczenia praktyk w przedszkolach i szkołach prowadzonych przez tutora (nauczyciel akademicki) i mentora (nauczyciel przedszkola i szkoły),

- zwiększenie funduszy na doskonalenie zawodowe nauczycieli ${ }^{21}$.

Teoretycy edukacji, określając współczesny model nauczyciela eksponują wybrane dyspozycje jednostki, które ich zdaniem sprawiają, że jest ona predestynowana do wykonywania założonych zadań. Można więc spotkać się z określeniami nauczyciela rozumianego jako: transformatywnego intelektualisty, animatora procesu edukacyjnego, inicjatora i koordynatora wychowania szkolnego i pozaszkolnego, doradcy, przewodnika i instruktora samokształcenia, indywidualności rozumianej jako wzór osobowy godny naśladowania, inspirato-

${ }^{17}$ Edukacja-jest w niej ukryty skarb..., s. 157.

${ }^{18}$ Tamże, s. 161.

${ }^{19}$ F. Mayor, Przysztość świata..., s. 382 i s. 378.

${ }^{20}$ A. Walenda, Nowe kompetencje potrzebne wspótczesnemu nauczycielowi- wybrane zagadnienia, [w:] L. Hurło, D. Klus- Stańska, M. Łojko, Paradygmaty wspótczesnej dydaktyki, Kraków 2009, s. 540.

${ }^{21}$ M. Żytko, Ksztatcenie nauczycieli... 
ra, przewodnika po świecie informacji naukowych i wartości, doradcy i partnera, arbitra, przewodnika i tłumacza budującego mądrość rozumienia świata i odpowiedzialności, interpretatora, transmitora i promotora wartości, autonomiczną tożsamość, nowatora i innowatora, terapeuty, badacza, współtwórcę nowoczesnej szkoły. Tak więc od nauczyciela wymaga się by był sprawnym rzemieślnikiem nauczania $i$ wychowania, a zarazem oczekuje się od niego, że stworzy wtasny autorski program nauczania, że indywidualnie podejdzie do rozpoznania $i$ wspierania rozwoju poszczególnych uczniów i to w sytuacji, gdy sq oni skupieni w bardzo licznych klasach szkolnych ${ }^{22}$.

Nowe obszary przygotowania i doskonalenia zawodowego nauczycieli, podstawowe tendencje kształcenia nauczycieli w zakresie określonych kompetencji przytacza Raport Eurydice, należą do nich:

1) coraz szersze stosowanie technologii informacyjnych i komunikacyjnych,

2) zwiększająca się autonomia w zarządzaniu placówkami szkolnymi,

3) rosnąca różnorodność środowisk społecznych i kulturowych,

4) zróżnicowane poziomy umiejętności, które można napotkać w jednej klasie (integracja uczniów posiadających specjalne potrzeby edukacyjne, kierowanie zachowaniami uczniów) ${ }^{23}$.

Kompetencje, które zdecydowanie przekraczają ramy wiedzy właściwej dla danego przedmiotu oraz umiejętności dydaktyczne. W przygotowaniu przyszłego nauczyciela na plan pierwszy wysuwają się: organizowanie i zarządzanie/administrowanie klasą (grupa) oraz kierowanie zachowaniami uczniów (dyscyplina). O ich istocie stanowią:

- w zakresie zarządzania i administrowania: zarządzanie finansami, kompetencje organizacyjne, zarządzanie czasem, umiejętności komunikacji i public relations,

- w zakresie kierowania zachowaniami uczniów oraz dyscypliny szkolnej: ogólne wprowadzenie do problematyki konfliktów w klasie, specjalistyczne kształcenie w zakresie komunikacji, kształcenie do asertywności, radzenie sobie ze stresem, panowanie nad gniewem, kształcenie praktyczne ukierunkowane na kierowanie zachowaniami uczniów ${ }^{24}$.

Rangę umiejętności nauczyciela w zakresie zarządzania zajęciami podkreślał Ch. Kyriacou, zwrócił on uwagę na sześć obszarów kompetencji kluczowych nauczyciela ${ }^{25}$ :

${ }^{22}$ A. Cichocki, Priorytet zmian $w$ organizacji pracy nauczycieli $w$ kontekście inicjatyw i tendencji międzynarodowych raportów edukacyjnych, [w:] J. Bielecki, A. Jacewicz (red.), Edukacja z perspektywy przemian kulturowo-społecznych. Wczoraj-dzi -- jutro, Białystok 2010 (prublikacja w druku).

${ }^{23}$ Raport EURYDICE „Zawód nauczyciela w Europie. Profil, wyzwania, kierunki zmian” raport I Ksztatcenie i poczqtki pracy zawodowej, Warszawa-Bruksela 2001.

${ }^{24}$ Tamże, s. 57, 62.

${ }^{25}$ Ch. Kyriacou, Essential Teaching Skills, Stanley Thornes Publishers Ltd, London 1991, cyt. za: R. Michalak, Kompetencje nauczyciela wspomagajacego rozwój matego dziecka, [w:] H. Sowińska, R. Michalak (red.), Edukacja elementarna jako strategia zmian rozwojowych dziecka, Kraków 2004, s. 205-218. 
1) planowania i przygotowania zajęć,

2) prowadzenia zajęć,

3) zarządzania zajęciami,

4) dyscypliny,

5) klimatu w klasie,

6) oceniania, monitorowania i ewaluowania pracy własnej oraz uczniów.

\section{Kwalifikacje zawodowe polskich nauczycieli i nauczycieli z wybranych krajów Europy}

Czas trwania i poziom wstępnego kształcenia nauczycieli w poszczególnych krajach Unii Europejskiej jest różny (schemat 1).

Schemat 1. Czas trwania kształcenia nauczycieli

\begin{tabular}{|c|c|c|c|c|c|}
\hline \multirow{2}{*}{\multicolumn{6}{|c|}{ Belgia }} \\
\hline & & & & & \\
\hline \multicolumn{6}{|l|}{ Dania } \\
\hline \multicolumn{6}{|l|}{ Niemcy } \\
\hline \multicolumn{6}{|l|}{ Grecja } \\
\hline \multirow{2}{*}{\multicolumn{6}{|c|}{ Hiszpania }} \\
\hline & \multirow{2}{*}{\multicolumn{5}{|c|}{$\begin{array}{l}\text { Francja } \\
\text { Irlandia }\end{array}$}} \\
\hline Irlandia & & & & & \\
\hline \multicolumn{6}{|c|}{ Włochy przed reforma } \\
\hline \multicolumn{6}{|c|}{ Włochy po reformie } \\
\hline \multicolumn{6}{|c|}{ Luksemburg } \\
\hline \multirow{2}{*}{\multicolumn{6}{|c|}{ Holandia }} \\
\hline & \multicolumn{5}{|c|}{ Portugalia } \\
\hline \multicolumn{6}{|l|}{ Szkocja } \\
\hline \multicolumn{6}{|l|}{ Austria } \\
\hline \multicolumn{6}{|l|}{ Finlandia } \\
\hline \multicolumn{6}{|l|}{ Szwecja } \\
\hline Islandia & & & & & \\
\hline Norwegia & & & & & \\
\hline
\end{tabular}

Legenda:

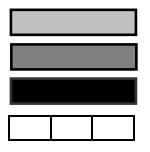

Kształcenie na poziomie wyższym nie uniwersyteckim.

Kształcenie uniwersyteckie.

Kształcenie na poziomie szkoły średniej.

Przygotowanie pedagogiczne teoretyczne i praktyczne

Źródło: Opracowanie własne w oparciu o E. Hoffmann (red.), Ksztatcenie przedszkolne i podstawowe w krajach Unii Europejskiej oraz krajach Europejskiego Stowarzyszenia Wolnego Handlu (EFTA) i Europejskiego Obszaru Gospodarczego (EEA), EUREDICE Europejska Sieć Informacji o Edukacji w Unii Europejskiej, Warszawa 1994 i 1996, s. 18-19. 
Kształcenie nauczycieli edukacji elementarnej w większości krajów odbywa się na poziomie szkolnictwa wyższego (rzadko na poziomie średnim, policealnym). Obowiązują dwa modele kształcenia nauczycieli: równoległy i etapowy.

Kształcenie nauczycieli przedszkoli i poziomu podstawowego najczęściej jest odrębne. Grecja, Hiszpania, Francja, Wielka Brytania, Finlandia, Szwecja i Włochy prowadzą kształcenie typu uniwersyteckiego. Prawie we wszystkich krajach Unii Europejskiej warunkiem wstapienia na studia dla nauczycieli przedszkoli jest posiadanie dyplomu lub świadectwa ukończenia szkoły średniej wyższej.

We Wtoszech dyplom scuola media, który odpowiada niższemu cyklowi szkoty średniej, nadal wystarcza do podjęcia studiów nauczycielskich. Nauczyciele przedszkoli i szkót podstawowych znacznie czesściej sq ksztatceni $w$ wyższych szkołach pedagogicznych. Przed reformq nauczyciele najniższego szczebla edukacji ksztatceni byli przez okres 4 lat na poziomie nie uniwersyteckim. Po reformie sugeruje się 5 letni okres ksztatcenia uniwersyteckiego ${ }^{26}$.

Instytucją ustalającą we Włoszech liczbę zatrudnianych nauczycieli jest Ministerstwo Oświaty. Aby mogli oni pracować w szkole wymagane jest od nich przygotowanie pedagogiczne. Jak w większości krajów UE, nauczyciele we Włoszech zatrudniani są najpierw na okres próbny, który zwykle trwa rok. Jest to jeden $\mathrm{z}$ istotnych warunków zdobycia uznania zawodowego lub uzyskania możliwości rejestracji w charakterze nauczyciela kwalifikowanego. Jest to niezbędny warunek zatrudnienia w szkołach publicznych.

Nauczycielom włoskim przyznaje się prawa urzędników państwowych, co wiąże się z wieloma przywilejami, np. gwarancją w utrzymaniu zatrudnienia aż do emerytury, dość wysokie zarobki, wysoką emeryturę (prawie 95\% poprzednich zarobków) oraz względnie wysoki prestiż społeczny ${ }^{27}$.

We Francji nauczycieli wczesnej edukacji kształci się na uniwersytetach, wymagany jest dyplom uniwersytecki licencjata (studia trzyletnie), oraz 2 lata w Instytucie Kształcenia Nauczycieli (IUFM)- przedmioty pedagogiczne, z zakresu specjalności, praktyki. Na drugim roku IUFM pracują już w szkole lub przedszkolu pod opieką tutora (otrzymują pensje).

W Danii oprócz dyplomu szkoły średniej wyższej trzeba mieć co najmniej dwuletnie doświadczenie zawodowe lub kwalifikacje równorzędne. W zależności od kraju po 3,4 lub 5 latach studiów, nauczyciel przedszkola otrzymuje dyplom kwalifikacji poziomu nie uniwersyteckiego - zawodowego. Wyjątek stanowi Hiszpania, Grecja, Francja i Wielka Brytania.

W Austrii siódma poprawka do ustawy z 1982 r. o organizacji systemu szkolnego tworzy podstawy aktualnego systemu kształcenia nauczycieli Kinder-

${ }^{26}$ A. Jacewicz, Edukacja przedszkolna w pótnocnych Włoszech, „Wychowanie w Przedszkolu" 2010, nr 1, s. 26.

${ }^{27}$ Tamże. 
garten. Otóż kształcenie rozpoczyna się w 7 roku nauki na poziomie szkolnictwa średniego wyższego i trwa 5 lat (15-19 r. ż.). Kończy się maturą i kwalifikacjami zawodowymi. Ci, którzy pomyślnie zdali egzamin, mogą zapisać się na studia uniwersyteckie. Od roku szkolnego 1994/95 kształcenie nauczycieli przedszkoli odbywa się w kolegiach (4 semestry). O przyjęcie mogą ubiegać się ci, którzy pomyślnie zdali maturę lub egzamin wstępny (Studienberechtigungsprüfung), upoważniający do studiowania na uniwersytecie.

W Anglii i Walii programy kształcenia nauczycieli nastawione są na wyposażenie studenta w wiedzę i umiejętności potrzebne mu do efektywnego nauczania. Wykwalifikowany nauczyciel wykazuje się następującymi umiejętnościami:

- znajomością i rozumieniem podstawy programowej przedmiotu, którego student ma w przyszłości uczyć,

- planowania i przygotowania lekcji, ustalania celów nauczania,

- kierowania klasa, powodowania właściwego zachowania się uczniów,

- przeciwdziałania dezorganizacji zajęć,

- efektywnego posługiwania się technologią informacyjną na lekcjach,

- świadomością oczekiwań społecznych od zawodu nauczyciela, wyznawanych przez niego wartości i zachowań w stosunku do uczniów i kolegów ${ }^{28}$.

Dużą wagę przywiązuje się do organizowania praktyk pedagogicznych. Obowiązkowe zajęcia, w co najmniej dwóch szkołach, w ciągu studiów wynoszą od 90 dni (18 tygodni) dla studentów po licencjacie przygotowujących się do pracy z małymi dziećmi - do 160 dni (32 tygodnie robocze) dla studentów 4-letnich studiów licencjackich ${ }^{29}$.

W Islandii studia trwają 3 lata. Kształcenie jest organizowane na poziomie szkolnictwa średniego wyższego, jednak w praktyce na poziomie wyższego, gdyż od kandydatów wymagane jest świadectwo uprawniające do wstępu na uniwersytet (studentspróf) lub dokumentu równorzędnego.

W Norwegii od kandydatów na nauczycieli przedszkoli wymaga się świadectwa ukończenia szkoły średniej wyższej.

Przygotowanie na poziomie wyższym nie uniwersyteckim jest wystarczające w: Belgii, Danii, Niemczech, Irlandii, Luksemburgu, Holandii, Portugalii, Austrii, Islandii. Ponadto w Austrii dopuszczalne jest wykształcenie na poziomie średnim, ale oprócz przygotowania teoretycznego wskazane jest przygotowanie praktyczne. W Niemczech trzeba posiadać świadectwo Realschule lub dyplom równorzędny. Po szoku związanym ze słabymi osiągnięciami niemieckich piętnastolatków (badania PISA) Niemcy bliscy są decyzji o zastąpieniu kształcenia nie uniwersyteckiego nauczycielek przedszkolnych uniwersyteckim.

\footnotetext{
${ }^{28}$ M. Pomianowska, K. Szczepkowska, J. Zawadowska, Przede wszystkim - dobrze ksztatcić nauczycieli, „Dyrektor Szkoły” 2009, nr 5.

${ }^{29}$ Tamże.
} 
W Grecji, Hiszpanii, Francji, we Włoszech (po reformie), Szkocji, Finlandii i Norwegii preferowane jest wyłącznie uniwersyteckie przygotowanie nauczycieli.

Zawód nauczyciela w Finlandii jest zbliżony prestiżem do zawodów inżyniera, prawnika czy lekarza, umożliwia także spełnienie się w profesji przynoszącej zadowolenie osobiste i zawodowe. Finowie darzą swoich nauczycieli ogromnym szacunkiem. Bycie nauczycielem jest równoznaczne z byciem człowiekiem wykształconym, pomagającym innym, wręcz mądrym. Takie słuszne przeświadczenie zostało ukształtowane $\mathrm{w}$ ciągu kilku ostatnich dziesięcioleci. $\mathrm{Na}$ wydziały uniwersyteckie kształcące nauczycieli ustawia się bardzo długa kolejka chętnych, że czasami kandydaci startują kilkukrotnie i się nie dostają, ponieważ konkurencja jest olbrzymia ${ }^{30}$.

Fińscy nauczyciele są wyjątkowi pod względem wiedzy jaką zdobyli w trakcie pięcioletnich studiów, a którą w całości wykorzystują w swojej pracy zawodowej z dziećmi. Selekcja do zawodu nauczyciela jest długa i trudna. Odbywa się na kilku poziomach. Rozpoczyna się od testu składającego się z 300 pytań mającego za zadanie ukazanie wiedzy przyszłego studenta m.in. z zakresu literatury czy umiejętności rozwiązywania różnorakich problemów. Na poziomie uniwersytetu kandydat do zawodu poddawany jest testom oceniającym jego zdolność do przetwarzania informacji, myślenia krytycznego i umiejętności syntezy danych. Jeśli kandydat poważnie myśli o byciu w przyszłości nauczycielem powinien być wśród $20 \%$ najlepszych studentów w grupie zdających. Następnym poziomem selekcji jest rozmowa (wywiad), w trakcie której sprawdza się motywację do nauczania, uczenia się, oceniane są także umiejętności komunikacyjne kandydata jego poziom inteligencji emocjonalnej, również sprawdzane są umiejętności pracy $\mathrm{w}$ grupie, oraz umiejętności interpersonalne ${ }^{31}$.

Kolejnym krokiem jest rekrutacja w szkole, w której kandydat chce podjąć pracę. Tylko najlepsi, którzy we wszystkich poprzednich sprawdzianach osiaggnęli najwyższy poziom, mają szansę na pracę w szkole. Nikogo zatem nie dziwi fakt, iż tylko jeden na dziesięciu kandydatów ma szansę uzyskać akceptację i zostać nauczycielem ${ }^{32}$.

Na przykładzie Uniwersytetu w Tampere na uczelni obowiązują trzy programy kształcenia nauczycieli:

50 studentów kształcących się na nauczycieli w przedszkolu (licencjat) BA, można ubiegać się o dokształcanie 3,5 roku - studia magisterskie.

74 przyszłych nauczycieli szkół podstawowych (studia magisterskie) - MA, 150 przyszłych nauczycieli szkół średnich (studia magisterskie)-MA.

${ }^{30}$ A. Puliński, Wybrane czynniki warunkujące powodzenie reform oświatowych w Finlandii, [w:] J. Bielecki, A. Jacewicz (red.), Edukacja z perspektywy przemian kulturowo- spotecznych. Wczoraj-dziś - jutro, Białystok 2010 (publikacja w druku).

${ }^{31}$ Tamże.

${ }^{32}$ Tamże, s. 20. 
Wydziały mają swój własny budżet (koszty utrzymania, pensje, wynajem budynków itp.), ministerstwo dzieli na wydziały około $100 \mathrm{mln}$. $€$. Stypendia naukowe i socjalne w $60 \%$ można otrzymać z uczelni, $40 \%$ można otrzymać z fundacji np. na cele badawcze, stypendia dla doktorantów. W zależności od kosztów utrzymania rodziny można liczyć na dofinansowanie państwa $(150-400 €)^{33}$.

Edukacja przedszkolna to w Finlandii nowa gałąź nauki. Oddzielny przedmiot nauczanie w przedszkolu jeszcze nie istnieje. Od sierpnia 1995 roku kształcenie nauczycieli przedszkoli odbywa się na poziomie uniwersyteckim i trwa trzy lata. W Tampere edukację nauczycieli rozpoczęto rok później. Program studiów pierwszych sześciu lat peruskoulu/grundskola obejmuje 160 godzin wykładów i prowadzi do dyplomu akademickiego. Głównymi przedmiotami są nauki o edukacji i metodyki nauczania. Nauczyciel zdobywa zarówno wiedzę teoretyczną, jak i praktyczna.

Kandydat na nauczyciela przedszkola podczas 3 lat studiów (licencjat) ma zdobyć 180 ECTS (punktów kredytowych), na które składają się 4 komponenty kształcenia (schemat 2).

Studenci mogą się ubiegać o przyjęcie na studia magisterskie. Jednak grupa przyjętych nie jest bardzo liczna - około 10 osób. Będą to przyszli dyrektorzy.

Schemat 2. Komponenty kształcenia nauczyciela przedszkola

\section{ECTS -przedmioty ogólne, kształcenie pedagogiczne,}

60 ECTS -zajęcia praktyczne, praktyki studentów w placówkach,

20 ECTS -języki obce, przedmioty ogólne, technologia informacyjna,

\section{ECTS -zajęcia fakultatywne wybrane przez studentów.}

Źródło: opracowanie własne w oparciu o materiały seminaryjne z wyjazdu szkoleniowego do Tampere.

${ }^{33}$ A. Jacewicz, Edukacja przedszkolna w Finlandii, „Wychowanie w Przedszkolu” 2009, nr 2, s. 27. 
Etap licencjatu kończy praca dyplomowa (10 ECTS z pierwszego komponentu) - stanowi ją od 4 do 6 stron. Są to zwięzłe, konkretne przemyślenia związane z wykonywaniem przyszłego zawodu ${ }^{34}$.

Szkoła podstawowa obejmuje 9 lat nauki (od 7 do 16 r. ż.) składa się z dwóch poziomów (stopni): klasy 1-6 najczęściej prowadzi jeden nauczyciel oraz klasy 7-9 uczą specjaliści przedmiotowi przygotowujący do pracy w szkole średniej. Należy podkreślić, że zawód nauczyciela postrzegany jest bardzo wysoko. Zainteresowanie kształceniem również jest bardzo duże - na 1000 kandydatów przyjęto 74 studentów.

Aby uzyskać tytuł magistra trzeba zdobyć 300 punktów ECTS.

Mocną stroną fińskiego systemu oświaty są praktyki, które dzielą się na: 2-3 okresy praktyk w szkołach ćwiczeń, trzeci okres praktyk odbywa się w szkole na terenie miasta (opiekun praktyk otrzymuje pieniądze z uniwersytetu). Koszt realizowania praktyki za studenta wynosi $1300 €$.

Kształcenie nauczycieli szkół jest organizowane oraz nadzorowane przez Ministerstwo Oświaty i odbywa się na szczeblu uniwersyteckim.

Schemat 3. Komponenty kształcenia nauczycieli szkół podstawowych

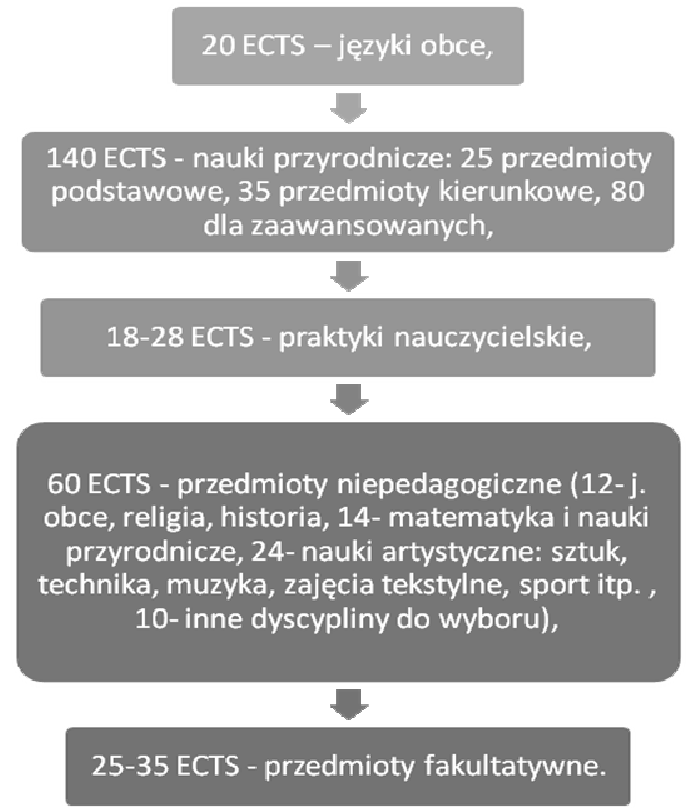

Źródło: opracowanie własne w oparciu o materiały seminaryjne z wyjazdu szkoleniowego do Tampere.

\footnotetext{
${ }^{34}$ Tamże.
} 
Należy stwierdzić, że pod wieloma względami fińscy nauczyciele mają ułatwiona pracę, gdyż nie posiadają tak licznych klas, jak szkoły w innych krajach europejskich. Dlatego nauczyciel ma o wiele większe możliwości dotarcia do każdego ucznia, który ma trudności z przyswojeniem materiału. Sami nauczyciele przyznają, że gdyby mieli uczyć w klasach liczących 30 i więcej osób, to wyniki ich pracy nie byłyby tak spektakularne. Jednak w fińskich warunkach stworzenie trzech klas liczących po 20- 22 uczniów zamiast dwóch 32 osobowych klas, nie stanowi większego problemu finansowego, który byłby w wielu krajach nie do pokonania.

Należy podkreślić, że fińscy nauczyciele mają bardzo dużą swobodę w ustalaniu programów nauczania, które nie są zbytnio przeładowane wiedzą encyklopedyczna. Olbrzymi nacisk kładzie się na zdobywanie wiedzy praktycznej.

Jeden lub dwoje nauczycieli prowadzi klasę w ciagu pierwszych 6 lat, co wiąże się to posiadaniem o wiele większego zasobu wiedzy z różnych obszarów nauki. Ciekawostką jest to, że gdy czuje się on niezbyt pewnie w jakieś dziedzinie, np. w śpiewie, może wymienić się ze swoim kolegą i poprowadzić zajęcia, w których ten drugi z kolei czuje się mniej kompetentny. Takie możliwości sprawiają, że szkoła fińska słynie z innowacyjności i stosowania niekonwencjonalnych metod działania ${ }^{35}$. Nauczyciele są specjalistami, którzy nie muszą być kontrolowani, oceniani i nadzorowani. Finowie wiedzą, że powierzają swoje dzieci wysokowykwalifikowanej kadrze pedagogicznej, której ufają, i z którą współpracują w trosce o dobro każdego wychowanka.

Priorytetem polityki oświatowej krajów Unii Europejskiej jest stworzenie nowego modelu nauczyciela. Powinien on mieć wyksztatcenie akademickie, umieć uczyć «innowacyjnie», a równocześnie być zdolnym do kształtowania tej umiejętności u swoich uczniów; sprawować nie tylko funkcje «kształceniowq», lecz również opiekuńczq, orientujq̨ca, selekcyjnq i koordynujacq; szybko i racjonalnie reagować na wszystko co postępowe i twórcze $[\ldots]^{36}$. Godne podkreślenia jest to, że nauczyciele powinni mieć także zamiłowanie do wykonywanej pracy i ustawicznie doskonalić swoje umiejętności zawodowe.

Kształcenie nauczycieli edukacji elementarnej w Polsce odbywa się na poziomach:

- 3 letnich studiów zawodowych (licencjackie),

- 2 letnich magisterskich,

- 5 letnich magisterskich.

Studia magisterskie można ukończyć na uniwersytetach, w akademiach pedagogicznych i wyższych szkołach pedagogicznych. Ponadto istnieje możliwość ukończenia studiów podyplomowych. Uczelnie wyższe prowadzą dla nauczycieli przedszkoli i klas I-III między innymi specjalizacje: edukacja przedszkolna,

\footnotetext{
${ }^{35}$ A. Puliński, Wybrane czynniki...

${ }^{36}$ C. Kupisiewicz, Szkolnictwo w procesie przebudowy, Warszawa 1987, s. 186.
} 
wczesnoszkolna, edukacja początkowa, kształcenie zintegrowane, wczesna edukacja, pedagogika wieku dziecięcego, edukacja wczesnoszkolna z językiem obcym, edukacja wczesnoszkolna ze sztuka, z przyroda, medialna, z technologia informacyjna, historią i społeczeństwem, edukacja wczesnoszkolna z terapią, logopedią, edukacja wczesnoszkolna z edukacją artystyczną $\mathrm{i}$ in.

Kolejnym krokiem w zmianie przygotowania kadr nauczycielskich powinno być podjęcie próby ujednolicenia systemu kształcenia - zapewnienie wykształcenia wyższego. Należy liczyć się z tym, że jest to proces długofalowy, gdyż wymaga ujednolicenia przepisów dotyczących m.in. zmian naboru, edukacji i wynagradzania nauczycieli.

Oczekiwania wobec współczesnych nauczycieli sugerują zmianę w przygotowaniu kandydatów do zawodu nauczycielskiego. Priorytetem w kształceniu winno stać się zbliżenie przyszłego nauczyciela do szkoły (przedszkola), klasy (grupy), ucznia (dziecka). W związku z tym należałby zwrócić uwagę na: szkołę (przedszkole) jako organizację i instytucję, podstawy prawne organizacji i funkcjonowania szkoły (przedszkola), przemiany w nadzorze pedagogicznym (rozwój dziecka, rozwój zawodowy nauczyciela, rozwój organizacyjny placówki i jej społeczna ocena), cykl działania zorganizowanego jako podstawa działania nauczyciela. Istotne jest planowanie, organizowanie, motywowanie, kontrolowanie itp.

Absolwent studiów pedagogicznych $z$ uprawnieniami nauczycielskimi, wkraczajacy do szkoły powinien: rozumieć podstawowe pojęcia z zakresu prawa oświatowego, znać podstawowe akty prawne określajace organizacje i funkcjonowanie systemu oświaty $i$ szkoty, znać procedury podejmowania racjonalnych decyzji, wiedzieć jak planować, organizować, motywować $i$ kontrolować realizacje celów $i$ zadań oraz efektów ksztatcenia, znać i stosować nowoczesne techniki pracy menedżerskiej $w$ organizacji pracy własnej $i w$ zespole uczniowskim $i$ nauczycielskim. To podstawowe $i$,konieczne” warunki sprawnych dziatań organizacyjnych nauczyciela stanowiqce nowy obszar $i$ „wyzwanie” w rozwoju tego zawodu ${ }^{37}$.

Jakość kształcenia nauczycieli ma podstawowe znaczenie dla zapewnienia jakości edukacji oraz poprawy wyników nauczania. Wszystkim nauczycielom potrzebny jest dostęp do wiedzy, postaw i umiejętności pedagogicznych, które są niezbędne do wydajnej pracy. Równie ważne jest wspieranie profesjonalizacji nauczania, kultury, refleksyjnej praktyki, badań wśród nauczycieli oraz podwyższenie statusu i zwiększenie uznania dla zawodu nauczyciela ${ }^{38}$.

Reasumując rozważania nad kształceniem nauczycieli edukacji elementarnej należy dostrzec nową misję szkoły, co ze sobą niesie poczynienie udoskonaleń w organizacji jej pracy. Wytyczne i kierunek działań wyznaczają między innymi raporty edukacyjne z lat $90 . \mathrm{XX}$ wieku i dokumenty Unii Europejskiej.

\footnotetext{
${ }^{37}$ A. Cichocki, Priorytet zmian...

${ }^{38}$ Komunikat Komisji...
} 
AGATA JACEWICZ

\section{Training teachers of elementary education in chosen European countries}

The author of the article underlines the growth of interest in kindergarten education as a significant link in educational system. Most of discussed problems refer to professional competences of early education teachers and the change of the role of a teacher who works with a young child. Directions of changes in training and development of kindergarten teachers and I-III classes are presented and professional qualifications of teachers from chosen European countries are described. The author also turns attention to the fact that the quality of training has basic significance in ensuring the quality of education as well as improving teaching results. Every teacher needs access to knowledge. Supporting professionalisation of teaching process, culture, self-reflective practice, research among teachers as well as enhancing the status and recognition of teaching profession are equally important. 